Tabligh: Jurnal Komunikasi dan Penyiaran Islam

Volume 1, Nomor 1 (2016) 1-24

Fakultas Dakwah dan Komunikasi, UIN Sunan Gunung Djati Bandung https://jurnal.fdk.uinsgd.ac.id/index.php/tabligh

\title{
Model Tabligh Salmanitb.com dalam Menyajikan Berita Islami
}

\author{
M. Ambang Fajar Hilman*, Sitty Sumijati, \& Bahrudin \\ Jurusan Komunikasi dan Penyiaran Islam, Fakultas Dakwah dan Komunikasi, \\ UIN Sunan Gunung Djati Bandung \\ *Email:mochamad_ambang@yahoo.com
}

\begin{abstract}
ABSTRAK
Tulisan ini mendeskripsikan model penerapan tabligh SalmanITB.com dalam menyajikan berita-berita Islami. Penelitian ini merupakan penelitian kualitatif-deskriptif menggunakan metode studi kasus. Teori yang digunakan adalah teori jurnalistik atau penyajian berita yang terdiri dari peliputan, penulisan, dan penyebarluasan berita. Penerapan tabligh SalmanITB.com dalam menyajikan berita-berita islami mengacu pada tiga proses utama (peliputan, penulisan, dan penyebarluasan berita) sebagaimana teori penyajian berita, dibuktikan dengan pengambilan sampel berita pada materi-materi yang dibutuhkan. Berdasarkan penemuan ini dapat disimpulkan bahwa model tabligh SalmanITB.com dalam menyajikan berita islami telah sesuai dengan aturan proses penyajian berita.
\end{abstract} Kata Kunci : model tabligh, media online, penyajian berita

\section{ABSTRAK}

This study describes the application model tabligh SalmanITB.com in presenting Islamic news. This research is a qualitative-descriptive research using case study method. The theory used is journalistic theory or news presentation consisting of coverage, writing, and dissemination of news with materials. After the research, it was found that the application of Tabligh SalmanITB.com in presenting Islamic news refers to three main processes (coverage, writing, and dissemination of news) as the theory of news presentation, evidenced by sampling news on the materials needed. Based on this finding, it can be concluded that SalmanITB.com's tabligh model in presenting Islamic news bas been in accordance with the rules of the news presentation process.

Keywords: tabligh model, online media, news presentation 


\section{PENDAHULUAN}

Dinamika dalam dunia dakwah meliputi banyak aspek. Media dakwah, diantaranya. Internet sebagai media dakwah membentuk karakteristik tersendiri dalam pelaksanaan dakwah, dengan berbagai ranting kegiatannya. Sebagai ranting kegiatan dakwah, tabligh menjadi bagian dari dinamika tersebut. Tabligh kini, tidak hanya merupakan kegiatan dakwah yang terjadi di dunia nyata. Tabligh menjadi lebih global dengan jaringan yang terbuka dan khalayak yang lebih luas yang terjadi di dunia maya. Menurut bahasa, tabligh adalah menyampaikan. Dalam Ilmu Dakwah, tabligh adalah penyampaian dan pemberitaan tentang ajaran-ajaran Islam kepada umat manusia, yang dengan penyampaian dan pemberitaan tersebut, pemberita menjadi terlepas dari beban kewajiban memberitakan dan pihak penerima menjadi terikat dengannya (Enjang, 2009: 53).

Masjid Salman ITB menjadi bagian yang tidak terpisahkan dalam dinamika dakwah ini. Dengan mendirikan situs informasi dan dakwah SalmanITB.com, menjadi bukti nyata bahwa kesempatan untuk mengembangkan ruang lingkup dakwah menjadi lebih luas dimanfaatkan demi masa depan dakwah itu sendiri. SalmanITB.com adalah situs yang memuat berita-berita islami, artikel-artikel kajian, rekaman multimedia dakwah, dan konten-konten lainnya. Situs ini berdiri pada Tahun 2009 dengan nama MasjidSalmanITB.com sebagai domain awalnya. Kegiatan menyebarkan informasi melalui media situs jejaring (website) ini sendiri termasuk bentuk kegiatan tabligh.

Masjid Salman ITB sendiri merupakan masjid yang memiliki sejarah perjuangan dakwah panjang di Indonesia. Masjid ini telah merayakan setengah abad kelahirannya sebagai pionir peradaban Islam melalui kampus-kampus akademik pada Tahun 2014 lalu. Kegiatan di Masjid Salman ITB termasuk: pengkaderan aktivis dan mahasiswa, pengkajian dan penerbitan, pemberdayaan masyarakat, pengembangan pendidikan, majelis taklim, pembinaan anak, lembaga ekonomi syariah, dan berbagai kegiatan lain melalui bidang dan unit khusus. SalmanITB.com sendiri merupakan bagian dari cabang marketing dan komunikasi dalam naungan Salman Media. Selain situs utama, terdapat sosial media sebagai bagian dari SalmanITB.com itu sendiri, diantaranya Facebook Fanspage, Twitter, dan Instagram.

Beralamat SalmanITB.com, Masjid Salman ITB memperluas jangkauan informasinya dengan menyajikan beragam konten yang segar 
dengan bumbu-bumbu 'inspirative journalism', menurut Tristia Riskawati, mantan pemimpin redaksi SalmanITB.com periode 2013-2015 yang kini menjadi Manajer Humas di YPM Salman ITB. Diwawancarai di back office Masjid Salman, Tristia mengatakan bahwa SalmanITB.com memiliki sebuah idealisme kejurnalistikan yang selalu berusaha untuk menebarkan inspirasi dan senantiasa memberi solusi.

"Nilai-nilai untuk senantiasa menginspirasi dan memberi solusi ini adalah bagian dimana kita ingin menampilkan wajah Islam yang ramah dan terbuka pada setiap kemajuan," (Riskawati, Wawancara 1 Januari 2016). Proses pemberitaan di Jepang, ia memisalkan, menampilkan kabar-kabar yang akar nilainya adalah untuk menumbuhkan harapan dan senantiasa menjaga kebersamaan ketika terjadi bencana atau musibah yang melanda dan bukan menampilkan kisah-kisah tragisme yang hanya menimbulkan emosi rasa kasihan dan menyerah pada keadaan. Sehingga masyarakat, sebagai khalayak konsumen berita, menjadi terinspirasi untuk saling membantu dan bekerja sama dalam membangun negara agar kembali stabil dan bahkan lebih baik dari sebelumnya.

Masjid Salman ITB adalah masjid yang dibangun oleh partisipasi masyarakat untuk menjunjung tinggi agama Islam dan mengembangkan kegiatan dakwah. Partisipasi masyarakat ini menjadi tanggung jawab sosial pihak pengurus YPM Salman ITB untuk senantiasa amanah dengan melaksanakan berbagai program kerja mulai dari optimalisasi kegiatan ibadah, dakwah, partisipasi sosial, kaderisasi, dan keilmuan. Untuk menunjang komunikasi yang transparan dan interaktif di antara Masjid Salman ITB dengan masyarakat maka ide untuk membuat sebuah portal informasi menjadi salah satu langkah terbaik. Dengan begitu SalmanITB.com didirikan.

Salim Rusli, Dewan Redaksi SalmanITB.com mengatakan, SalmanITB.com didirikan pada tahun 2009 dengan Iqbal Alfajri sebagai Pemimpin Redaksi. Pada waktu itu konten yang diterbitkan di SalmanITB.com adalah berita-berita tentang kegiatan Masjid Salman ITB saja. Pemenuhan mengenai informasi-informasi yang sifatnya "mengabarkan" pada waktu itu menjadi sebuah hal yang perlu ditindaklanjuti dengan penyediaan informasi yang lengkap dan akurat itu sendiri. Hal inilah yang mendasari mengapa SalmanITB.com didirikan.

Salim melanjutkan ada dua fungsi utama SalmanITB.com pada saat didirikan, yaitu: Pertama, fungsi kehumasan, sebagai portal penghubung antara kegiatan-kegiatan di Masjid Salman ITB berupa kegiatan dakwah, 
sosial, pendidikan, dan lain-lain dengan khalayak pengakses informasi maupun para donatur Masjid Salman ITB yang merasa perlu mengetahui bagaimana pemanfaatan partisipasi sosial dalam bentuk kegiatan positif; dan kedua, fungsi kaderisasi, dimana pelaksanaan kegiatan jurnalistik di SalmanITB.com adalah untuk membentuk mahasiswa atau kader-kader Masjid Salman memiliki karakter jurnalis yang berpegang teguh pada aturan-aturan agama Islam dengan tidak menyimpang untuk memberitakan sesuatu yang negatif atau berita-berita palsu. Dengan demikian ramai kegiatan jurnalisme di Indonesia menjadi diwarnai oleh kader-kader jurnalis Islam yang senantiasa ingin menyampaikan dakwah.

Semenjak berdiri pada tahun 2009 hingga kini, SalmanITB.com memiliki tubuh keorganisasian yang ramping. Hal ini dikarenakan ruang lingkup kegiatan jurnalistik di Masjid Salman yang relatif terbatas. Para pegiatnya kebanyakan adalah mahasiswa-mahasiswa yang berkuliah di Kota Bandung, seperti Institut Teknologi Bandung (ITB), Universitas Padjadjaran (Unpad), Universitas Pendidikan Indonesia (UPI), dan UIN Sunan Gunung Djati Bandung. Dalam kurun waktu tersebut SalmanITB.com pun secara otomatis hanya terdiri dari beberapa bagian keredaksian, seperti Pemimpin Redaksi, Koordinator Liputan, Redaktur, dan Reporter.

SalmanITB.com telah melalui regenerasi hingga keredaksian Tahun 2016. Ditandai dengan perubahan pemimpin redaksi, maka sistem keredaksian SalmanITB.com pun menyesuaikan dengan situasi dan kondisi pada waktu tersebut. Berikut ini nama-nama pemimpin redaksi SalmanITB.com dari waktu ke waktu: 1) Iqbal Al-Fajri, 2) Yudha P. Sunandar, 3) Maya Mustika Dewi, 4) Tristia Riskawati, dan 5) Nadhira Rizki.

Tulisan ini mendeskripsikan model penerapan tabligh SalmanITB.com dalam menyajikan berita-berita Islami dengan rumusan masalah: 1) Bagaimana manajemen Salman Media sebagai Mubaligh? 2) Bagaimana penyajian berita Islami di SalmanITB.com? 3) Bagaimana proses peliputan sumber berita di SalmanITB.com? 4) Bagaimana penulisan berita Islami di SalmanITB.com? dan 5) Bagaimana penyebarluasan berita Islami kepada khalayak?

\section{METODE PENELITIAN}

Masalah yang timbul di dalam penelitian ini adalah adanya kegiatan tabligh yang dilaksanakan oleh Salman Media dengan media SalmanITB.com. 
Melalui situs ini, Salman Media melaksanakan bermacam-macam kegiatan tabligh yang salah satunya adalah kegiatan penyajian berita. Berdasarkan masalah ini, penulis tertarik untuk menguraikan model penyajian berita tersebut dalam bentuk uraian yang lengkap dan sistematis maka dari itu penelitian ini menggunakan pendekatan kualitatif-deskriptif. Selanjutnya berdasarkan pendekatan yang dilakukan sebelumnya, maka penulis menggunakan metode studi kasus sebagai alat bedah dalam penelitian ini.

Data primer dikumpulkan dari hasil wawancara secara langsung dengan kepala/ketua redaksi, para penulis/reporter berita, editor SalmanITB.com, begitu juga dewan redaksi SalmanITB.com sebagai pengarah kebijakan SalmanITB.com. Wawancara menggali informasi yang berkaitan dengan kegiatan proses penyajian berita islami di SalmanITB.com. Dari wawancara ini, penulis mendapatkan data mengenai kegiatan penyajian berita sejak tahap yang paling pertama hingga yang paling terakhir. Selain itu, penyusun mengambil data-data primer lainnya berupa berita-berita yang tergolong sebagai berita islami. Berita-berita ini diambil sebagai bahan penelitian dengan pengambilan sampel berita yang diterbitkan pada Tahun 2014-2016.

Pengambilan sampel dalam penelitian ini menggunakan teknik Pengambilan Sampel Purposif (Purposial Sampling). Menurut Sanapiah Faisal (2010: 67), teknik ini adalah teknik yang menetapkan sampel secara sengaja oleh peneliti. Dalam hubungan ini, penelitian didasarkan atas kriteria atau pertimbangan tertentu, jadi tidak melalui teknik random.

Pengambilan sampel yang berkisar pada Tahun 2014-2016 bermaksud dengan mempertimbangkan untuk merepresentasikan gaya pemberitaan tabligh SalmanITB.com dalam kurun waktu yang paling terkini. Berdasarkan sebaran populasi berita yang terbit pada interval waktu tersebut, penyusun mengambil sampel penelitian berdasarkan kebutuhan materi analisis pada bagian-bagian yang dianggap perlu mencantumkan contoh berita sebagai sampel. Pengambilan sampel ini penyusun anggap memang tidak dapat merepresentasikan secara total keseluruhan berita di dalam situs SalmanITB.com namun setidaknya dapat merepresentasikan materi yang ditulis dan membantu proses analisis.

Untuk observasi dan penelitian langsung dilaksanakan di Kantor Redaksi Salman Media, YPM Salman ITB Jl. Ganesha No. 5 Kecamatan Coblong, Kota Bandung, Provinsi Jawa Barat. Penentuan lokasi ini didasarkan pada pertimbangan bahwa pada lokasi tersebut tersedia sumber data yang diperlukan mengenai keredaksian SalmanITB.com. 
Penelitian diawali dengan melaksanakan observasi terhadap objek penelitian yaitu situs jejaring SalmanITB.com. Situs ini didapati merupakan sebuah situs yang terkonsentrasi pada pemberitaan kegiatan-kegiatan keislaman khususnya mengenai kegiatan Masjid Salman ITB dan artikelartikel serta media lain yang bernilai islami. Setelah melihat kecocokan objek penelitian dengan latar belakang program studi, penelitian dilanjutkan dengan observasi secara langsung untuk berkomunikasi dengan subjek penelitian yaitu pihak unit Salman Media, sebagai unit yang menaungi SalmanITB.com. Observasi ini dilaksanakan sebagai pondasi bahan penelitian untuk dikembangkan lebih jauh pada penelitian selanjutnya.

Setelah observasi awal, penelitian langsung mengarah pada pengambilan data-data primer berupa keterangan mengenai kegiatan tabligh (baca: penyajian berita islami) yang dilaksanakan oleh redaksi SalmanITB.com melalui wawancara. Dalam kegiatan wawancara ini, penulis mewawancarai Pemimpin Redaksi Salman Media Nadhira Rizki, Manajer Biro Kehumasan, Marketing dan Komunikasi sekaligus mantan Pemimpin Redaksi Salman Media Tristia Riskawati, Dewan Redaksi Salman Media Salim Rusli, Pendiri SalmanITB.com sekaligus mantan Pemimpin Redaksi Salman Media Yudha P. Sunandar, dan Reporter Salman Media Fathia Uqimul Haq. Melalui proses wawancara ini, data-data primer telah terkumpul sebagai bahan utama penulisan jurnal ini.

Untuk memperkuat keterangan yang diberikan para narasumber wawancara pada langkah penelitian sebelumnya, penulis mengambil sampel berita yang digolongkan sebagai "berita islami" sebagai bahan pendukung analisis. Latar belakang pengambilan sampel ini sudah dijelaskan pada paragraf sebelumnya. Sampel-sampel berita ini mendukung analisis dan hasil penelitian mengenai proses penyajian berita yang dilaksanakan oleh redaksi SalmanITB.com yang terdiri dari peliputan, penyajian, dan penyebarluasan berita.

Selanjutnya dalam proses analisis, penulis menggunakan analisis kualitatif. Menurut Faisal (2010: 255-256), penelitian yang menggunakan format studi kasus, baik terhadap individu atau kelompok, lazimnya menggunakan analisis kualitatif bukan analisis kuantitatif. Studi kasus, sebagaimana telah disebutkan pada bagian-bagian terdahulu, diharapkan berlangsung intensif, mendalam, komprehensif, rinci, dan tuntas. Dabbs (Faisal, 2010: 255-256) mengatakan, "Quality is the essential character or nature of something; quantity is the amount. Quality is the what; quantity is the how much. Qualitative refers to the meaning ... while quantitative assumes the meaning and refers 
to a measure of it."

Oleh karena itu analisis kualitatif fokusnya pada penunjukan makna, deskripsi, penjernihan dan penempatan data pada konteksnya masingmasing, dan seringkali melukiskannya di dalam kata-kata daripada di dalam angka-angka. Berdasarkan hal tersebut maka proses analisis data di dalam penelitian ini menggunakan analisis kualitatif.

Sebagai pelaksana kegiatan tabligh, unit Salman Media melalui keredaksian SalmanITB.com melaksanakan kegiatan tabligh yang dalam berbagai bentuk. Bentuk-bentuk ini pada dasarnya memiliki kesamaan, yaitu penyampaian pesan yang nilainya islami kepada khalayak. Untuk mengetahui bagaimana pelaksanaan tabligh di SalmanITB.com maka perlu diuraikan secara rinci bagaimana proses pelaksanaannya. Pertanyaan bagaimana proses pelaksanaan tabligh di SalmanITB.com sekurangkurangnya dapat mewakili pertanyaan pertama dalam penelitian ini.

Kemudian pelaksanaan penyajian berita merupakan kegiatan utama dalam penyajian informasi dan dakwah pada situs SalmanITB.com itu sendiri. Sebagai situs informasi, berita menjadi bagian yang tidak terpisahkan dan dianggap sebagai komoditi utama. Berita memiliki sumber nilai ketertarikan khalayak untuk mengakses sebuah situs atau halaman informasi. Kemudian bagaimana proses pelaksanaan penyajian berita islami sebagai bagian dari bentuk kegiatan tabligh? Pertanyaan kedua ini merumuskan masalah utama dalam penelitian mengenai pelaksanaan pemberitaan di media situs SalmanITB.com. Penelitian ini akan menguraikan proses tersebut dan menyusunnya dalam sebuah model agar dapat dimanfaatkan pihak lain yang memiliki kepentingan dalam kaitannya dengan kegiatan penyajian berita islami melalui media online. Secara etimologi, kata model menurut Kamus Ilmiah Populer dikatakan sebagai suatu pola, contoh, aturan ragam, dan sesuatu yang akan dibuat atau dihasilkan. Mengutip Book, Hafied Cangara (2008: 39) menggambarkan model sebagai berikut:

Hampir semua di antara kita pernah mengunjungi pameran atau museum. Di sana diperlihatkan berbagai macam miniatur seperti gedung, candi, pesawat terbang, perahu, dan sebagainya. Miniatur-miniatur seperti dimaksud adalah model. Model ialah suatu gambaran yang sistematis dan abstrak, di mana menggambarkan potensi-potensi tertentu yang berkaitan dengan berbagai aspek dari sebuah proses.

Penelitian mengenai "Model Tabligh SalmanITB.com dalam Menyajikan Berita Islami" memiliki kerangka pemikiran yang didasarkan 
pada dua konsep utama yang terlahir dari pertanyaan penelitian sebelumnya yaitu "Tabligh SalmanITB.com" dan "Penyajian Berita Islami". Dalam menjelaskan bagaimana proses penyajian berita islami yang dilaksanakan oleh SalmanITB.com tentunya perlu dijelaskan terlebih dahulu kegiatan tabligh secara umum yang dilaksanakan oleh SalmanITB.com itu sendiri.

\section{HASIL DAN PEMBAHASAN}

Masjid Salman ITB sebagai masjid kampus pertama di Indonesia merupakan salah satu masjid tersibuk. Selain terbuka bagi jamaah selama 24 jam, Masjid Salman pun memiliki agenda kegiatan yang begitu tinggi dalam setiap bulannya. Agenda yang beberapa bulan terakhir menjadi salah satu agenda yang rutin dilaksanakan setiap bulannya adalah Salman A Days Out Picnic. Kegiatan ini merupakan kegiatan piknik bagi jamaah di pelataran Masjid Salman ITB dengan rangkaian kegiatan yang beraneka ragam seperti multilomba, pentas seni, pelatihan, seminar, bazzar dan lain-lain. Kegiatan ini pun adalah satu kegiatan utama yang dilaksanakan oleh Biro Kehumasan, Marketing, dan Informasi Salman ITB dalam membentuk citra Masjid Salman sebagai masjid yang ramah dan inklusif bagi semua kemajuan dan perkembangan peradaban umat manusia.

Dengan tingginya jumlah kegiatan Masjid Salman melingkupi bidangbidang dan unit-unitnya, maka kehadiran media massa sebagai sarana dokumentasi dan informasi menjadi hal mutlak yang mesti dilaksanakan. Pelaksanaan kegiatan pemberitaan ini melingkupi seluruh bagian-bagian atau unsur-unsur utama dalam komunikasi mengingat pemberitaan SalmanITB.com adalah salah satu bentuk kegiatan komunikasi.

Dalam melaksanakan pemberitaan tersebut, SalmanITB.com jika diturunkan dari pendekatan ilmu komunikasi dan dikaji menggunakan pendekatan ilmu tabligh maka memiliki beberapa unsur utama, yaitu mubaligh, maudhu' tabligh, uslub tabligh, wasilah tabligh, mubalagh, dan tujuan tabligh serta respon tabligh dan konteks tabligh sebagai situasi dan implikasi yang tak terpisahkan ketika terjadi proses tabligh (Fatoni, 2003: 10). 
Model Tabligh SalmanITB.Com dalam Menyajikan Berita Islami

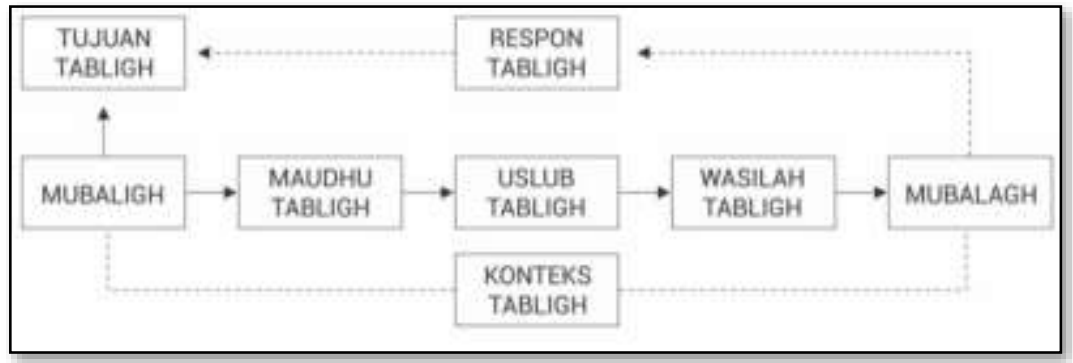

Gambar 1: Proses Pelaksanaan Tabligh berdasarkan Unsur-Unsurnya

Proses pelaksanaan tabligh berdasarkan unsur-unsurnya diturunkan dari pendekatan ilmu komunikasi dan pendekatan ilmu dakwah dimana hal ini melibatkan berbagai unsur sebagaimana Gambar 1 di atas. Dalam proses ini, mubaligh menjadi unsur pertama sebagai sumber dan/atau pelaksana kegiatan tabligh (Shodiqin, 2012: 366). Selanjutnya mubaligh merangkai pesan tabligh (maudhu) menggunakan metode-metode (uslub) tertentu. Dalam penyampaian pesan tabligh ini, mubaligh juga tentunya menggunakan media (wasilah) tertentu agar pesan tersebut dapat diterima oleh jamaah (mubalagh) sehingga tujuan tabligh dapat dicapai. Dalam menentukan tujuan tabligh, seorang atau sekelompok mubaligh mesti melakukannya sejak awal agar proses pelaksanaan tabligh tetap terarah sebagaimana tujuan yang telah ditetapkan. Selain proses utama tersebut ada situasi dan implikasi yang melekat dalam proses pelaksanaan tabligh, yaitu respon tabligh dan konteks tabligh. Respon ini adalah situasi dan implikasi dimana mubalagh telah menerima pesan yang disampaikan oleh mubaligh. SalmanITB.com kaitannya dalam proses pelaksanaan tabligh dapat digambarkan melalui pendekatan ilmu tabligh dengan menguraikan setiap unsur-unsurnya. Keenam unsur ditambah dua unsur tambahan ini dapat mewakili secara garis besar pelaksanaan kegiatan tabligh dalam sebuah media massa.

\section{Manajemen Salman Media sebagai Mubaligh}

Unsur pertama dalam proses pelaksanaan tabligh adalah mubaligh. Mubaligh adalah seseorang atau sekelompok orang yang menyampaikan pesan-pesan tabligh kepada orang lain secara langsung atau tidak langsung melalui lisan, tulisan atau perbuatan untuk mengamalkan ajaran-ajaran Islam atau menyebarluaskan ajaran Islam, melakukan upaya perubahan ke arah kondisi yang lebih baik menurut ajaran Islam. Mubaligh dalam posisi 
ini disebut subjek tabligh, yaitu pelaku aktif kegiatan tabligh sebagai proses penyampaian ajaran Islam.

Konteksnya situs SalmanITB.com, mubaligh merupakan sekelompok orang yang tergabung dalam kegiatan pemberitaan sebagai pembuat pesan, yaitu meliputi manajemen redaksi Salman Media termasuk di dalamnya Dewan Redaksi, Pemimpin Redaksi, Redaktur, IT Support, Designer, Admin Media Sosial, dan Reporter.

Maudhu Tabligh dalam Sumber-Sumber Berita. Berita yang diproduksi oleh SalmanITB.com merupakan berita-berita yang berasal dari sumber-sumber yang telah ditentukan dalam rapat redaksi maupun belum ditentukan dilihat berdasarkan kebutuhan berita tersebut. Berita-berita yang mengandung komentar atau pendapat seorang tokoh dalam sebuah kajian atau pidato tentu termasuk sumber-sumber berita yang telah ditentukan sebelumnya. Bahkan sebuah berita bisa jadi tidak bernilai apabila tokoh atau penceramah tersebut tidak dijadikan sumber berita. Berbeda hubungannya dengan berita-berita yang diangkat dari event atau kegiatan-kegiatan nonceramah atau non-kajian, jika manajemen redaksi menginginkan sebuah komentar atau testimoni dari peserta kegiatan, maka reporter yang harus secara fleksibel menentukan siapa yang berhak diwawancarai.

Tabel 1: Daftar Manajemen Salman Media Bulan Oktober 2016

\begin{tabular}{|c|c|c|}
\hline Nama & $\begin{array}{c}\text { Jabatan } \\
\text { (Salman Media) }\end{array}$ & $\begin{array}{c}\text { Jabatan } \\
\text { (YPM Salman) }\end{array}$ \\
\hline Khirzan N. Noe'man & Dewan Redaksi & $\begin{array}{l}\text { Direktur Biro Kehumasan, } \\
\text { Marketing, dan Komunikasi }\end{array}$ \\
\hline Tristia Riskawati & Dewan Redaksi & $\begin{array}{l}\text { Manajer Biro Kehumasan, } \\
\text { Marketing, dan Komunikasi }\end{array}$ \\
\hline Nadhira Rizki & Pemimpin Redaksi & Kepala Divisi Media \\
\hline Khilda Husain A. & $\begin{array}{l}\text { Wakil Pemred/Koor. } \\
\text { Liputan }\end{array}$ & Wakil Divisi Media \\
\hline Ekky & IT Support & - \\
\hline Aikhalid N. & Admin Media Sosial & - \\
\hline Zaenal Muttaqin & Designer & - \\
\hline Fathia Uqimul Haq & Reporter & - \\
\hline Ana Shofiya Kurniawati & Reporter & - \\
\hline
\end{tabular}

Berdasarkan wawancara bersama Pemred Salman Media Nadhira Rizki, jika diuraikan isi pesan dalam berita-berita yang ditulis di 
SalmanITB.com meliputi 7 (tujuh) hal, yaitu sebagai berikut: 1) Events: Kegiatan-kegiatan yang berhubungan dengan Masjid Salman ITB, termasuk di dalamnya kegiatan yang dilaksanakan oleh bidang-bidang dan unitunitnya; 2) Kabar: Informasi terbaru mengenai segala hal yang berhubungan dengan Masjid Salman ITB, seperti wafat seorang tokoh Salman atau rencana pembangunan Masjid Salman; 3) Pencapaian: Progress atau kemajuan seperti prestasi salah seorang aktivis Masjid Salman ITB dalam skala nasional; 4) Pendapat Tokoh: Pemikiran atau anggapan seseorang yang memiliki kredibilitas tentang suatu wacana atau gejala sosial; 5) Isu-Isu Sosial: Peristiwa atau wacana yang terjadi di masyarakat dan dianggap dapat menjadi perhatian jamaah Masjid Salman ITB; 6) Jajak Pendapat (Vox Pop): Pendapat masyarakat umum secara acak untuk melihat anggapan umum dari permukaannya secara langsung, dan 7) Kajian: Isi materi kajian, seminar, atau pelatihan yang dilaksanakan di Masjid Salman ITB.

Beberapa hal di atas dapat merepresentasikan keseluruhan berita yang tersebar di dalam situs SalmanITB.com. Berita-berita di dalam situs ini banyak berisi berita-berita yang memang berhubungan secara langsung dengan Masjid Salman ITB disebabkan fungsi kehumasannya. Namun jika dilihat secara lebih terbuka, pesan-pesan yang terdapat di dalam beritaberita tersebut selalu menyampaikan nilai-nilai pesan dakwah.

SalmanITB.com sebagai portal media islami warga, tentu menyampaikan informasi dengan metode penulisan atau kitabah yang dalam hal ini kegiatan jurnalistik. Namun jika dilihat melalui situsnya langsung, konten yang mengisi situs tersebut tidak hanya tulisan tanpa metode yang lainnya.

SalmanITB.com juga menggunakan metode fotografi, grafis, audio visual, mp3, dan halaman interaksi sebagai bagian dari metode tabligh yang digunakan dalam menyampaikan pesan-pesannya. Metode-metode ini digunakan untuk meningkatkan kualitas situs itu sendiri. Situs informasi yang baik memang dapat menyajikan informasi dalam bentuk yang bermacam-macam. Pembaca selalu menginginkan sesuatu yang menarik untuk dikonsumsi oleh mereka. Dengan metode-metode ini situs SalmanITB.com dapat memenuhi kebutuhan dari para pembaca atau mubalagh tersebut. Jika metode untuk menyampaikan informasi dapat menarik perhatian dari khalayak, maka bukan tidak mungkin respon mereka akan memberikan pengaruh positif terhadap keberlangsungan situs ini.

Manajemen SalmanITB.com yang tergabung dalam divisi media 


\section{Ambang Fajar Hilman, Sitty Sumijati, \& Bahrudin}

Salman ITB atau lebih akrab dengan Salman Media, memproduksi informasi untuk disebarluaskan kepada khalayak pembaca ranah maya melalui dua media yaitu website dan media sosial. Penggunaan website sebagai media utama SalmanITB.com menjadi sumber konten pada publikasi yang dilakukan melalui media sosial. SalmanITB.com memiliki beberapa media sosial sebagai sambungan interaktif dan alternatif dari mengakses situs utama, yaitu fanspage Facebook, Instagram, dan Twitter.

Khalayak Pembaca (Mubalagh) sebagai Sasaran Tabligh. Pembaca, dalam hal ini mubalagh, dalam kegiatan tabligh SalmanITB.com adalah pengguna internet yang mengakses situs SalmanITB.com dan/atau yang menjadi follower media sosial SalmanITB.com sebagaimana telah diuraikan pada sebelumnya. Menurut Pemred Nadhira Rizki, SalmanITB.com sendiri memfokuskan diri pada segmentasi mubalagh dari kalangan akademisi dan mahasiswa. Kedua segmentasi ini didasarkan pada mayoritas jamaah Masjid Salman adalah kedua golongan tersebut. Selain itu, manajemen SalmanITB.com sendiri terdiri dari kalangan akademisi dan mahasiswa.

Tujuan Tabligh SalmanITB.com Proses pelaksanaan tabligh SalmanITB.com pada awalnya, menurut Yudha P. Sunandar, mempunyai 3 (tiga) tujuan yaitu: Membentuk Karakter Kritis melalui Pendidikan Jurnalis, Menjadi Media Warga (Citizen Media) dan Melaksanakan Tugas Dakwah sebagai Media Kehumasan Masjid Salman ITB

Selain keenam unsur tersebut, peninjauan proses pelaksanaan tabligh dapat dilihat dari kedua unsur yang melekat (iltizam) pada enam unsur utama. 1) Respon Balik (Feedback) dalam Kegiatan Tabligh SalmanITB.com. Jika proses pelaksanaan tabligh telah menyeluruh, maka akan ada implikasi yang terjadi selanjutnya. Dalam media online, sebagaimana SalmanITB.com, feedback ini dapat terjadi secara langsung dan cepat. Berbeda dengan media massa konvensional (cetak dan elektronik) yang memiliki feedback namun tertunda. Secara tidak langsung pengaruh tabligh dari SalmanITB.com dapat berimplikasi ke dalam pemikiran mereka terhadap sesuatu wacana. Respon seperti ini yang kemudian akan memengaruhi sikap mereka selanjutnya. Selain menjadi bahan evaluasi tersendiri bagi pihak mubaligh, respon dari khalayak akan menjadi penilaian terhadap kualitas sebuah media. Respon yang baik akan menjadi penilaian positif bagi SalmanITB.com dan begitu juga sebaliknya. 2) Konteks Tabligh SalmanITB.com. Tabligh dilaksanakan dalam suatu konteks atau situasi tertentu. Secara luas, konteks tabligh dapat diartikan sebagai faktor di luar unsur-unsur utama dati tabligh itu sendiri, yang terdiri dari: pertama, aspek 
bersifat fisik seperti iklim, cuaca, suhu, udara, bentuk ruangan, dan alat yang tersedia untuk menyampaikan pesan tabligh; kedua, aspek psikologis seperti: sikap, kecenderungan, prasangka, dan emosi peserta tabligh; ketiga, aspek sosial seperti: norma kelompok, nilai sosial, dan karakteristik budaya khalayak; dan keempat, aspek waktu yakni kapan melaksanakan kegiatan tabligh. Konteks tabligh dalam pelaksanaannya dapat diklasifikasikan ke dalam berbagai istilah-istilah lain selain dari ke empat aspek di atas. Istilahistilah tersebut menggunakan istilah tingkat, bentuk, keadaan, jenis, cara, situasi, dan pertemuan. Indikator paling umum untuk mengklasifikasikan tabligh berdasarkan konteksnya adalah dengan menggunakan ukuran tingkatnya atau jumlah peserta yang terlibat ke dalam kegiatan tabligh tersebut. Jika menggunakan pendekatan tingkatan komunikasi, maka tabligh SalmanITB.com termasuk ke dalam komunikasi massa. Dengan begitu konteks tabligh di SalmanITB.com adalah tabligh menggunakan media massa.

\section{Penyajian Berita Islami di SalmanITB.Com}

Setelah mengamati proses pelaksanaan tabligh SalmanITB.com melalui peninjauan secara mendalam pada unsur-unsurnya, selanjutnya adalah dengan meninjau penerapan proses pelaksanaan tabligh

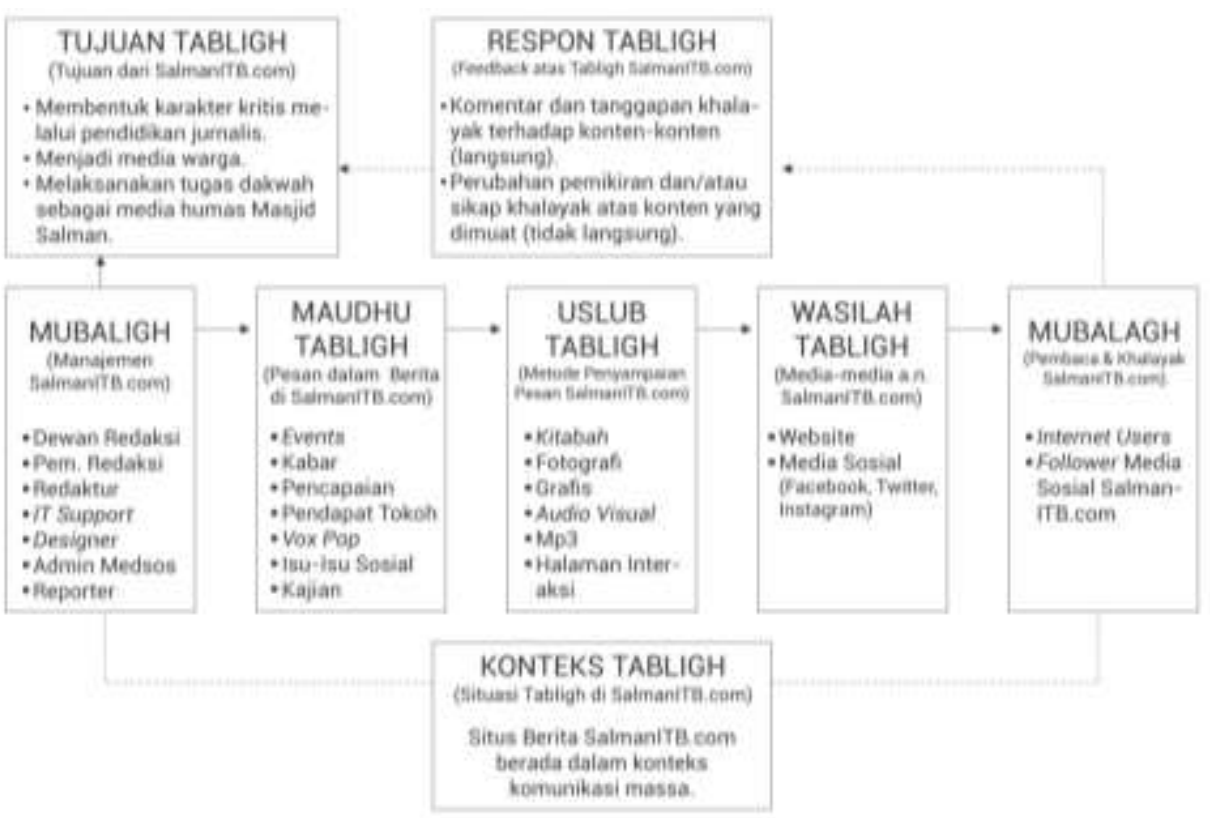

Tabligh: Jurnal Komunikasi dan Penyiaran Islam Vol. 1 No. 1 (2016) 1-24 


\section{Ambang Fajar Hilman, Sitty Sumijati, \& Bahrudin}

SalmanITB.com dalam kaitannya pada kegiatan penyajian berita islami. Jika pendekatan untuk meninjau rangkaian kegiatan tabligh SalmanITB.com melalui pendekatan unsur-unsur ilmu komunikasi, maka pendekatan proses

Gambar 2: Proses Pelaksanaan Tabligh di SalmanITB.com

Jurnalistik menjadi pisau bedah dalam menguraikan proses penyajian berita dalam situs ini. Berdasarkan definisi dari Asep Syamsul M. Romli (2012: 11-12) bahwa kegiatan jurnalistik adalah proses peliputan, penulisan, dan penyebarluasan informasi (aktual) atau berita melalui media massa. Ada tiga bagian utama dalam proses penyajian berita yang secara umum digunakan oleh setiap media massa, yaitu peliputan, penulisan berita, dan penyebarannya. Bagian respon khalayak secara langsung tidak memengaruhi proses ini, tetapi hal ini menjadi sebuah implikasi dari proses penyajian berita itu sendiri.

\section{Proses Peliputan Sumber Berita di SalmanITB.Com}

Dalam kegiatan jurnalistik, kegiatan liputan menjadi hal mutlak yang harus dilaksanakan. Konteksnya dalam tabligh, liputan adalah kegiatan mencari bahan-bahan maudhu tabligh atau pesan yang akan disampaikan dalam kegiatan tabligh kepada khalayak mubalagh. Kegiatan liputan ini dilaksanakan oleh mubaligh atau reporter untuk mencari bahan-bahan tersebut ke sumber-sumber berita.

Tabel 2: Rencana Liputan Salman Media September - Oktober 2016

\begin{tabular}{lll}
\hline Agenda Liputan & Peliput & Deadline \\
\hline Kajian Muslimah Cakrawala & Shofi & \\
Kajian Sabtu Dhuha & Ucen & \\
Soft Launching PPOB & Fathia & 19 September 2016 \\
Edukasi ketakmiran & Fathia & 19 September 2016 \\
Pelatihan guru LPP & Shofi & \\
Bandung Adha Fest & Shofi & \\
Opening LMD & Shofi & 1 Oktober 2016 \\
Pembukaan kelas akting gel. 2 & Shofi & 30 September \\
Kajian Ifthar & Fathia & 1 Oktober 2016 \\
Lipsus kebencanaan & Fathia dan Shofi & 2 Oktober 2016 \\
Sains spiritual camp & Fathia & 6 Oktober 2016 \\
Pembukaan beasiswa perintis & Shofi & 6 Oktober 2016 \\
Ulang tahun PAS & Shofi & 9 oktober 2016
\end{tabular}


Model Tabligh SalmanITB.Com dalam Menyajikan Berita Islami

Peringatan 1 Muharram

Syukuran wisuda

Salman homedicare
Fathia

Shofi

Fathia
14 Oktober 2016

17 Oktober 2016

14 Oktober

Sebelum melaksanakan proses peliputan, setiap media mempunyai rencana peliputan yang telah dirapatkan terlebih dahulu. Rapat ini disebut dengan rapat perencanaan berita (Zaenuddin, 2011: 81-82). Setiap minggunya, Salman Media mengadakan rapat untuk merencanakan liputan. Rapat ini biasa dilaksanakan pada hari Selasa. Dalam rapat dibahas mengenai evaluasi liputan selama satu minggu ke belakang, rencana liputan dalam satu minggu ke depan, dan berbagai hal lain yang berhubungan dengan kegiatan liputan.

Setelah perencanaan liputan, reporter SalmanITB.com turun ke lapangan untuk mencari sumber-sumber berita. Telah diterangkan sebelumnya mengenai proses peliputan, sumber-sumber berita dapat berasal dari 8 (delapan) sumber yaitu Tempat Kejadian Perkara (TKP), Wawancara, Konferensi Pers, Pers Release, Pidato (Ceramah atau Pertemuan), Jajak Pendapat (Vox Pop), Rumor, dan Gosip.

Sejatinya dalam pelaksanaan peliputan di SalmanITB.com, menurut Pemred Nadhira Rizki, tidak menggunakan keseluruhan sumber berita untuk mendapatkan isi pesan dari berita-berita yang diterbitkan melalui media ini. Disebabkan karena ruang lingkup yang tidak begitu luas, beritaberita di Salman ITB.com hanya menggunakan beberapa sumber berita saja, yaitu wawancara, pidato, jajak pendapat, konferensi pers dan kutipankutipan pembicara dalam kajian. 1) wawancara subjek bernilai. Beberapa berita mengambil sudut pandang pendapat tokoh tentang sesuatu wacana atau kejadian. Subjek bernilai di sini maksudnya adalah tokoh atau orang penting yang berhubungan dengan objek berita yang akan diangkat. Pendapat orang-orang penting tersebut merupakan salah satu komposisi berita yang dapat mengangkat nilai kelayakan berita itu sendiri. 2) pengutipan pidato. Reportase atau liputan dengan mengutip pidato merupakan salah satu bagian dari teknik liputan yang dilaksanakan di SalmanITB.com sejauh ini. Liputan dengan mengutip pidato biasanya dilaksanakan ketika ada sebuah pembukaan kegiatan, seremoni, atau pengumuman dari pihak-pihak yang memiliki hubungan dengan kegiatan yang bersangkutan. 3) wawancara jajak pendapat. Wawancara jenis ini adalah wawancara kepada kerumunan atau sumber-sumber yang bertebaran dengan alasan untuk mengambil respon atau anggapan tentang suatu isu, 
wacana, atau kegiatan yang berlangsung di Masjid Salman atau menjadi bahan obrolan banyak orang. Jajak pendapat (vox pop) ditujukan kepada sumber acak (random) karena tidak ditentukan oleh manajemen redaksi sebelumnya. Hal yang lebih penting di sini adalah komentar atau pendapatnya, bukan orang yang mengatakannya. 4) Pengutipan Materi Kajian. Masjid Salman ITB sebagai masjid yang memiliki peran sebagai laboratorium ruhani, tidak hanya menjadi pusat ibadah saja. Berbagai kajian atau seminar menjadi agenda rutin yang tidak pernah absen setiap minggu. Ada kalanya para pembaca SalmanITB.com adalah orang-orang yang ingin mengetahui isi kajian dalam pertemuan rutin tersebut, namun tidak bisa menghadiri karena berbagai alasan, menurut Pemred Nadhira Rizki. Sebagai alternatif, maka mereka mencari intisari-intisari dari kajian tersebut melalui SalmanITB.com, salahsatunya.

Proses liputan di SalmanITB.com sejauh ini hanya menggunakan beberapa metode atau teknik yang telah disebutkan di atas. Terkadang dalam satu berita, reporter juga mengkombinasikan beberapa cara di atas untuk menambah unsur-unsur kredibilitas sebuah berita.

\section{Penulisan Berita Islami di SalmanITB.com}

Proses selanjutnya di dalam penyajian berita adalah proses penulisan berita. Setiap peristiwa dan/atau pendapat yang telah diliput oleh reporter kemudian ditulis dalam bentuk berita. Dalam proses ini seorang reporter atau penulis berita dituntut untuk mengerti bagaimana penulisan berita dengan baik. Hal ini akan berhubungan langsung dengan bagaimana pembaca akan menanggapi berita tersebut. Berita yang tidak menarik, pembaca tidak akan memedulikannya. Berita yang buruk, pembaca akan mengurangi respect pada media yang menerbitkan berita tersebut. Kecakapan seorang penulis dalam merangkai sebuah berita untuk kemudian disajikan kepada pembaca mencakup bagaimana ia memahami nilai berita, unsur berita, gaya bahasa, dan komposisi naskah.

Berdasarkan observasi penyusun pada tanggal 29 September 2016, SalmanITB.com sebagai situs portal informasi memuat tiga jenis berita tersebut ke dalam situsnya. Jumlah masing-masing jenis berita tidak menentu namun berita dengan jenis straight news memiliki jumlah yang lebih banyak daripada depth news dan feature. Jika ditinjau berdasarkan konsep penulisan berita beberapa hal dapat menjelaskan bagaimana proses penulisan berita di SalmanITB.com sebagai sebuah situs berita.

Berdasarkan observasi penyusun pada situs tersebut bahwasanya 
nilai-nilai berita yang paling sering menjadi bagian dari berita-berita di SalmanITB.com adalah berita yang mengandung nilai immediacy, proximity, emotion, prominence, dan progress. Pertama, Kebaruan atau Immediacy. Saat mengakses sebuah situs berita, tentu saja berita yang paling terbaru yang menjadi perhatian setiap pembaca. Dalam berita berjudul "Masjid Salman Salurkan Kurban ke Palestina dan Syiria" ini menggunakan nilai kebaruan pada waktunya yaitu tertanggal Selasa, 27 September 2016 untuk memberitakan tentang rangkaian Idul Adha:

Idul Adha tahun ini terasa spesial untuk Masjid Salman ITB. Tahun ini, Masjid Salman menyalurkan dua ekor unta ke Palestina dan Syiria. Ini adalah pertama kalinya Salman menyalurkan hewan kurban ke luar negeri.

Di Salman sendiri, jumlah hewan kurban yang terhimpun hingga Hari Raya Idul Adha Senin (12/9) lalu mencapai puluhan ekor. Lebih dari 40 ekor kambing dan 20 ekor sapi disembelih kemudian disalurkan dagingnya ke daerah-daerah sekitar Salman dan Kampung Bangkit. Salman juga menyalurkan daging hewan kurban ke wilayah luar Pulau Jawa, seperti Aceh, Lampung, dan Papua. "Salman menyalurkan hewan kurban yang akan disembelih di Sumedang, Ciamis, Garut, Kabupaten Bandung, Aceh, Kendari, Lampung, dan Wamena Papua," tutur Staf Rumah Amal Salman ITB Riki Ramdhani.

Selain disalurkan, daging hewan kurban yang terhimpun di Salman juga diolah menjadi sate dan gulai. Kedua makanan tersebut dibagibagikan secara gratis pada acara perayaan Idul Adha tahunan Salman, Bandung Adha Fest, Ahad (18/9) lalu. Event bertajuk "Semarak Qurban Berjuta Manfaat" tersebut dihadiri oleh ratusan pengunjung dari Kota Bandung dan sekitarnya.[ed: Dh] (Kurniawati, Ana Shofiya. 2016. Masjid Salman Salurkan Kurban ke Palestina dan Syiria. Salman ITB. Web. 11 Oktober 2016. http:/ / kabar.salmanitb.com)

Kedua, Kedekatan atau Proximity. Peristiwa yang memiliki nilai jarak atau proximity menjadi bagian yang tidak terpisahkan dari berita-berita yang diterbitkan oleh SalmanITB.com. Jarak yang dimaksud di sini tidak selalu mengenai jarak berdasarkan hitungan lokasi. hal ini pun termasuk di dalamnya mengenai jarak hubungan seperti kedekatan keluarga, saudara, atau sebagainya. Dengan memberitakan Masjid Salman ITB pun sudah termasuk ke dalam berita-berita yang mengandung kedekatan dengan para jamaah Masjid Salman.

Ketiga, Ketertarikan Manusia atau Emotion. Ketertarikan manusia 


\section{Ambang Fajar Hilman, Sitty Sumijati, \& Bahrudin}

biasanya dikenal dengan buman interest akan tetapi hal ini bisa dikategorikan ke dalam nilai emotion atau emosi. Pada dasarnya istilah-istilah tersebut memang memiliki hakikat yang sama, yaitu tentang sesuatu yang berhubungan dengan rasa ingin tahu manusia karena suatu gejolak emosi baik senang, sedih, marah, kecewa, dan lain-lain. Berita-berita yang memiliki nilai ini biasanya ditulis dalam bentuk feature dengan pertimbangan bahwa berita dalam jenis ini memiliki fleksibilitas dan tidak terpatok pada aturanaturan yang baku.

Keempat, Ketermukaan atau Prominence. Ketermukaan atau prominence selalu berhubungan dengan seseorang atau sekelompok orang. Ketermukaan dapat ditinjau dari sejauh mana ketertarikan masyarakat pada orang atau kelompok tersebut. Sebut saja imam muda Muzammil Hazbullah, sarjana arsitektur ITB yang suaranya menjadi viral di internet, dapat dikategorikan sebagai orang yang memiliki ketermukaan sendiri. Ketika sebuah berita menjadikan Muzammil sebagai objeknya, maka berita tersebut akan menjadi perhatian tersendiri.

Kelima, Kemajuan atau Progress Berita yang mengandung nilai kemajuan atau perkembangan sesuatu hal dapat menjadi berita yang menarik perhatian pembaca. Berita yang mengandung nilai ini adalah berita yang layak untuk diterbitkan. Kemajuan di sini adalah mengenai peningkatan sesuatu hal, umumnya adalah perkembangan programprogram sebuah kelompok atau bisa jadi perkembangan sebuah isu-isu sosiall.

Keenam, Unsur Berita. Dalam setiap proses penulisan berita, reporter atau penulis tentu harus memerhatikan unsur-unsur berita. Unsur dalam setiap berita minimal menggunakan pola $5 \mathrm{~W}+1 \mathrm{H}$ yaitu what (apa), who (siapa), where (dimana), when (kapan), why (kenapa) dan how (bagaimana). Berita-berita mendalam (depth news) dan feature pun tentu harus ditulis dengan pondasi ini, selain menambahkan unsur-unsur lain seperti kutipan lagu, pepatah, undang-undang, dan lain-lain. Untuk mengetahui apakah berita di SalmanITB.com memiliki nilai tersebut, penyusun mengambil berita berjudul "KBIH Salman: Rombongan dalam Kondisi Aman" berikut ini sebagai contoh:

Bandung, (Salman Media) - Musibah kembali menimpa jemaah haji di Mekkah. Setelah kecelakaan jatuhnya alat derek besar (crane) di kompleks Masjidil Haram, kecelakaan terjadi lagi di Mina, tepatnya di jalan menuju tempat lontar jumrah. Kecelakaan yang terjadi pada pukul 07.00 pagi waktu setempat Kamis (24/9) kemarin itu 
disebabkan adanya sekelompok jemaah yang tiba-tiba berhenti, mengakibatkan penumpukan jemaah.

Republika.co.id melaporkan, Juru Bicara Kementerian Luar Negeri (Kemlu) RI Arrmanatha Nasir dalam siaran pers mengungkapkan, sebagian besar korban adalah jemaah dari Mesir dan Afrika. Jalur tempat kejadian sendiri bukan jalur yang biasa digunakan oleh jemaah asal Indonesia.

Sementara itu, sebanyak 86 orang rombongan Kelompok Bimbingan Ibadah Haji (KBIH) Salman ITB dilaporkan berada dalam kondisi aman dan sehat wal afiat. Staf KBIH Salman, Tian Sumarna mengatakan, informasi tersebut pihaknya terima Kamis kemarin.

"Alhamdulillah jemaah haji Salman aman, sehat, dan lancar menjalankan lempar jumrohnya," ujar Tian, Jumat (25/9).

Rombongan sendiri dijadwalkan sampai di Bandung pada tanggal 25 Oktober mendatang, pukul 08.00 WIB. (Rizki, Nadhira. 2015. KBIH Salman: Rombongan dalam Kondisi Aman. Salman ITB. Web. 11 Oktober 2016. http://kabar.salmanitb.com)

Berita di atas memiliki unsur 5W+1H. Jika diuraikan, unsur what terdapat di dalam kalimat "Musibah kembali menimpa jemaah haji di Mekkah". Kemudian unsur who dalam berita tersebut dapat dilihat di dalam kalimat "... menimpa jemaah haji di Mekkah", “... Juru Bicara Kementerian Luar Negeri (Kemlu) RI Arrmanatha Nasir dalam siaran pers mengungkapkan ...”, “... sebanyak 86 orang rombongan Kelompok Bimbingan Ibadah Haji (KBIH) Salman ITB ...”. Setelah itu unsur when dan where masing-masing terdapat di dalam kalimat "Kecelakaan yang terjadi pada pukul 07.00 pagi waktu setempat Kamis (24/9) kemarin itu ..." dan “... kecelakaan terjadi lagi di Mina ..."

Selanjutnya unsur kenapa atau why terdapat di dalam kalimat “... disebabkan adanya sekelompok jemaah yang tiba-tiba berhenti, mengakibatkan penumpukan jemaah." Terakhir unsur how dapat ditinjau dalam kalimat "Alhamdulillah jemaah haji Salman aman, sehat, dan lancar menjalankan lempar jumrohnya."

Ketujuh, Gaya Bahasa, Sebagai media jurnalistik, SalmanITB.com mengikuti panduan umum gaya bahasa jurnalistik sebagaimana telah diterangkan sebelumnya. Dasar-dasar dari gaya bahasa jurnalistik adalah singkat, padat, sederhana, lugas, menarik, dan jelas. Berikut ini berita berjudul "Mampir ke Salman, Wakil Presiden Gelorakan Kekuatan Ekonomi Muslim" di bawah ini untuk melihat apakah berita di 


\section{Ambang Fajar Hilman, Sitty Sumijati, \& Bahrudin}

SalmanITB.com menggunakan dasar-dasar gaya bahasa jurnalistik:

Bandung, (Salman Media) - Kekuatan ekonomi umat Muslim. Begitu kiranya yang menjadi inti yang Jusuf Kalla sampaikan pada Talkshow Inspirasi Ramadhan, Ahad (19/6/2016) lalu. Bertempat di Ruang Utama Masjid Salman ITB, Wakil Presiden Republik Indonesia ini mempersoalkan ihwal muzakki (pemberi zakat) yang masih terlampau sedikit.

"Kita (umat muslim.red) kekurangan orang kaya. Muzakki sedikit. Mustahik (penerima zakat) nya banyak," ujar Jusuf.

Ia berseloroh, di antara 100 orang kaya di Indonesia, 10 persennya orang Islam. Hal ini menandakan jika orang Islam kaya adalah minoritas. Sedangkan di antara 100 orang miskin di Indonesia 90 persennya adalah orang Islam. Berarti, orang Islam miskin adalah mayoritas.

Lantas, bagaimana agar orang Islam berkekuatan secara ekonomi? Jusuf berpendapat, kuncinya adalah mengolah ilmu-ilmu pengetahuan yang melimpah ini agar bernilai ekonomi.

"Di era yang mulai diisi oleh Generasi Y (anak muda sekarang.red), kita sangat akrab dengan IT. Ada teknologi lain seperti nanoteknologi, manufacturing, dan lain sebagainya. Tinggal bagaimana kita men-shift ilmu-ilmu ini menjadi bisnis," papar pria yang populer disebut JK ini.

Selain JK, Rektor Institut Teknologi Bandung (ITB) Kadarsah Suryadi juga turut memberikan sambutan. Kadarsah menekankan jika ia mulai merintis ITB menjadi berbasis kewirausahaan.

"Dalam membentuknya, dibutuhkan 4 aspek yang biasa saya singkat sebagai 4R, rasio, raga, rasa, dan religi," papar Kadarsah. Ketua Umum YPM Salman ITB Syarif Hidayat juga turut memberikan sambutan. Ia mengingatkan agar umat Muslim jangan terlalu terlena dengan keindahan Alquran, tetapi juga bersemangat mengaplikasikannya. Ruh inilah yang menjadi penghidup gerakan kaderisasi di Salman.

"Kita tak mencetak kader partai, tetapi kita mencetak kader-kader peradaban," simpul Syarif. (Riskawati, Tristia. 2016. Mampir ke Salman, Wakil Presiden Gelorakan Kekuatan Ekonomi Muslim. Salman ITB. Web. 11 Oktober 2016. http://kabar.salmanitb.com)

Dalam berita di atas penulis menggunakan gaya bahasa jurnalistik sebagaimana uraian sederhana berikut ini: 1) Singkat. Salah satu kalimat 
yang menggunakan gaya bahasa yang singkat adalah kalimat pertama "Kekuatan ekonomi umat Muslim". Penulis lebih kurang sebenarnya bermaksud untuk menuliskan "Sejauhmana kekuatan yang dimilki oleh umat Muslim". Namun untuk mengikuti gaya bahasa jurnalistik, penulis menghapuskan kata "sejauhmana" dan "yang dimiliki oleh" karena terlalu bertele-tele dan menjelaskan sesuatu dengan terlalu panjang. 2) Padat. Dalam berita di atas, kalimat padat terdapat pada kalimat "Bertempat di Ruang Utama Masjid Salman ITB, Wakil Presiden Republik Indonesia ini mempersoalkan ihwal muqakei (pemberi zakat) yang masih terlampau sedikit." Pada kalimat tersebut dapat diambil tiga poin yaitu "Bertempat di Ruang Utama Masjid Salman ITB" sebagai unsur where, "Wakil Presiden Republik Indonesia ini" sebagai unsur who, "mempersoalkan ihwal muzakki (pemberi zakat)" sebagai unsur what, dan "yang masih terlampau sedikit" sebagai unsur how. 3) Sederhana. Selanjutnya mengenai gaya bahasa yang sederhana dapat dilihat di dalam kalimat "Kadarsah menekankan jika ia mulai merintis ITB menjadi berbasis kewirausahaan”. Kalimat tersebut menampilkan kalimat single yang terdiri dari subjek, predikat, dan objek. Kalimat yang sederhana sendiri adalah kalimat yang terdiri dari kalimatkalimat pendek atau bukan merupakan kalimat majemuk yang sangat panjang. 4) Lugas. Gaya bahasa lugas adalah gaya bahasa yang mengungkapkan kalimat secara langsung dan tidak berbunga-bunga. Kalimat "Hal ini menandakan jika orang Islam kaya adalah minoritas" adalah salah satu contohnya. Selain itu kalimat "Ketua Umum YPM Salman ITB Syarif Hidayat juga turut memberikan sambutan" dan kalimat "Kita tak mencetak kader partai, tetapi kita mencetak kader-kader peradaban" dapat merepresentasikan pengungkapan kalimat secara lugas. 5) Menarik. Untuk menjadikan sebuah kalimat menarik, penulis menggunakan kalimatkalimat yang masih hidup digunakan oleh masyarakat. Bahkan ada bahasabahasa serapan asing yang mulai dipergunakan tetapi sudah sangat akrab seperti dalam kalimat "Tinggal bagaimana kita men-shift ilmu-ilmu ini menjadi bisnis". Kata "shift" dapat diartikan sebagai "merubah". Kata ini telah dipergunakan oleh banyak orang, sehingga penggunaannya menjadikan tulisan lebih menarik karena mengakomodir bahasa-bahasa yang sedang berkembang. 6) Jelas. Kalimat "Selain JK, Rektor Institut Teknologi Bandung (ITB) Kadarsah Suryadi juga turut memberikan sambutan" dapat diambil sebagai contoh kalimat yang menggunakan gaya bahasa yang jelas. Pertama, penggunaan kata "JK", telah menjadi keakraban umum yang menjelaskan tentang akronim dari nama "Jusuf Kalla". 


\section{Ambang Fajar Hilman, Sitty Sumijati, \& Bahrudin}

Terlebih sosok Jusuf Kalla telah disebutkan pada bagian sebelumnya. Maka dari itu kata tersebut sudah jelas. Kedua, untuk istilah yang belum diperjelas seperti ITB, maka kata tersebut dijelaskan terlebih dahulu sebelum dituliskan dalam bentuk singkatan. 7) Komposisi Naskah. Setiap jenis berita memiliki komposisi naskahnya masing-masing. Straight news, depth news, dan feature dibentuk dengan komposisi naskah yang berbeda-beda di antara satu sama lain. Begitu pun berita-berita yang diterbitkan oleh SalmanITB.com memiliki perbedaan komposisi naskahnya.

\section{Penyebarluasan Berita Islami kepada Khalayak}

Berita-berita di dalam situs SalmanITB.com pada umumnya adalah berita yang ditujukan pada segmentasi mahasiswa dan akademisi yang termasuk di dalamnya para donatur, jamaah, dan para pembaca umum. Hal ini diutarakan oleh pemimpin redaksi Salman Media, Nadhira Rizki. Segmentasi mahasiswa dan akademisi memang disebabkan karena Masjid Salman adalah masjid yang dibangun oleh para aktivis yang merupakan akademisi, mahasiswa, dan/atau pernah menjadi mahasiswa. Terlebih jamaah Masjid Salman setiap harinya adalah jamaah yang berlokasi di daerah Tamansari atau sekitar kampus Institut Teknologi Bandung.

Setelah melewati proses penulisan, tulisan yang layak untuk diangkat menjadi berita dengan menerbitkannya di dalam situs SalmanITB.com ditentukan terlebih dahulu category-nya. Saat ini ada lebih dari 20 kategori di dalam situs SalmanITB.com jika dihitung secara keseluruhan namun kurang dari 10 (sepuluh) category yang dapat mengakomodir bentuk tulisan atau berita. Berdasarkan observasi penyusun, setiap berita digolongkan pada category tertentu didasarkan pada kesamaan ciri-ciri spesifik dalam satu berita dengan berita yang lainnya.

\section{PENUTUP}

Berdasarkan hasil penelitian dan pembahasan mengenai penelitian ini maka penyusun mengambil kesimpulan sebagai jawaban atas rumusan masalah. Secara umum, SalmanITB.com melaksanakan kegiatan tabligh dengan keenam unsurnya, yaitu: Pertama, mubaligh dalam kegiatan tabligh dalam situs SalmanITB.com adalah manajemen redaksi SalmanITB.com yang tergabung dalam Salman Media yaitu Dewan Redaksi, Pemimpin Redaksi, Wakil Pemimpin Redaksi, IT Support, Admin Media Sosial, Designer, dan Reporter; Kedua, pesan atau maudhu tabligh di dalam proses ini adalah event Masjid Salman ITB, kabar-kabar sekitar Masjid Salman, Pencapaian atau 
progress umat muslim, pendapat-pendapat para tokoh, isu-isu sosial, jajak pendapat masyarakat, dan kutipan kajian di Masjid Salman; Ketiga adalah uslub tabligh berupa kitabah (tulisan), fotografi, audio visual, mp3, infografis, dan halaman interaktif; Keempat, media tabligh berupa website dan media sosial facebook, twitter, dan instagram; Kelima, mubalagh yaitu khalayak pembaca situs SalmanITB.com atau follower media sosialnya; dan terakhir, keenam, tujuan tabligh SalmanITB.com sebagai sarana pendidikan jurnalistik, media warga, dan media kehumasan Masjid Salman ITB. Selanjutnya respon tabligh di SalmanITB.com terlihat dari komentarkomentar langsung di dalam situsnya sedangkan konteks tablighnya adalah komunikasi media massa.

Penyajian berita islami di SalmanITB.com sesuai dengan aturan dasar proses penyajian berita, yaitu peliputan sumber data, penulisan berita, dan penyebarluasannya kepada khalayak. Dalam peliputan, ada 4 (hal) yang sering menjadi bahan untuk penulisan berita yaitu, wawancara subjek bernilai, pengutipan pidato, wawancara jajak pendapat (vox populi), dan pengutipan materi kajian, seminar, atau pelatihan. Selanjutnya dalam penulisan berita, SalmanITB.com memerhatikan 4 (empat) aspek utama yaitu, nilai berita (timeliness, proximity, emotion, prominence, dan progress), unsur berita $(5 \mathrm{~W}+1 \mathrm{H})$, gaya bahasa (singkat, padat, sederhana, lugas, menarik, dan jelas), dan komposisi naskah berdasarkan aturan straight news, depth news, dan feature news. Terakhir, proses penyebarluasan berita tersebut melalui situs SalmanITB.com dengan memerhatikan segmentasi (akademisi dan mahasiswa) dan category (Warta, Feature, Telusur, Pojok Salman, What's Hip, Kabar Unit, Lensa, Parade Ide, Ekspresi, Salman TV, Rekaman Ceramah, Dakwah, Berita Utama, Ramadan dan lain-lain).

Adapun rekomendasi penyusun setelah menyelesaikan penelitian ini adalah sebagai berikut: 1) Model yang dilaksanakan oleh SalmanITB.com dalam menyajikan berita-berita islami ini dapat terus dipertahankan dengan tetap memproduksi konten-konten islami sebagai bagian dari sarana membentuk wacana kritis mahasiswa atau aktivis, menjadi media warga dengan peduli pada isu-isu sosial, serta tetap menjalankan kegiatan jurnalistik tersebut sebagai bagian dari tugas dakwah; 2) Untuk senantiasa konsisten dalam mempertahankan model tabligh SalmanITB.com dalam menyajikan berita islami, penyusun menganggap perlu pihak Salman Media untuk mempertahankan setiap anggota redaksi atau bahkan menambahkannya; 3) Fakultas Dakwah dan Komunikasi UIN Sunan Gunung Djati Bandung, khususnya jurusan Komunikasi dan Penyiaran 
M. Ambang Fajar Hilman, Sitty Sumijati, \& Bahrudin

Islam dapat menjadi salah satu pionir dalam pengembangan tabligh menggunakan media internet apakah itu berbentuk situs, media sosial, blog, dan lain-lain.

\section{DAFTAR PUSTAKA}

Cangara, H. (2008). Pengantar Ilmu Komunikasi. Jakarta: PT. Raja Grafindo Persada.

Enjang A.S., dan Aliyudin. (2009). Dasar-Dasar Ilmu Dakwah. Bandung: Widya Padjadjaran.

Faisal, S. (2010). Format-Format Penelitian Sosial: Dasar-Dasar dan Aplikasi. Jakarta: Rajawali Press.

Fatoni, U. (2003). Kredibiltas Kunci Sukses Muballigh. Bandung: Task Press.

Haq, F. U. (2015). Sekolah Pra Nikah Salman Fokus pada Masalah Terkini.

Web. 11 Oktober 2016. http:/ /kabar.salmanitb.com

Kurniawati, A. S. (2016). Masjid Salman Salurkan Kurban ke Palestina dan Syiria. Salman ITB. Web. 11 Oktober 2016. http:/ / kabar.salmanitb.com

Riskawati, T. (2016). Mampir ke Salman, Wakil Presiden Gelorakan Kekuatan Ekonomi Muslim. Salman ITB. Web. 11 Oktober 2016. http:/ / kabar.salmanitb.com

Rizki, N. (2015). KBIH Salman: Rombongan dalam Kondisi Aman. Salman ITB. Web. 11 Oktober 2016. http:/ / kabar.salmanitb.com

Romli, A. S. M. (2012). Jurnalistik Online:Panduan Praktis Mengelola Media Online (Dilengkapi Kiat Blogger, Teknik SEO, dan Tips Media Sosial). Bandung: Penerbit Nuansa Cendekia.

Shodiqin, A. (2012). Reposisi Muballigh: dari 'Personal menuju 'Agent of Change' dalam Ilmu Dakwah: Academic Journal for Homiletic Studies, 6 (2), 363-382.

Warson, A. M. (1984). Al-Munawwir Kamus Besar Arab Indonesia. Yogyakarta: Ponpes Al-Munawwir.

Zaenuddin, H. M. (2011). The Journalist: Bacaan Wajib Wartawan, Redaktur, Editor \& Para Mahasiswa Jurnalistik. Bandung: Simbiosa Rekatama Media. 